\title{
The Dark Side of the Moon
}

Heritage, memory and place in Rio de Janeiro, Brazil

José Reginaldo Santos Gonçalves

\begin{abstract}
In this paper the author focuses on the various ways people from an outlying area of the city of Rio de Janeiro, Brazil, understand the concepts of heritage, memory and place. Facing a radical transformation of their neighborhood conducted by the city government, they discuss the destiny of an old movie theater that is threatened with demolition. Some of them understand it as a heritage site to be protected and preserved because it supposedly expresses the memory of the neighborhood. Others affirm that the best way to deal with the problem is to demolish the old building and construct a new public square. The point made by the author is that we are facing two quite distinct ways of understanding the concept of heritage: one of them is based on an abstract and legal perspective; the other based on the everyday life experience of local residents.
\end{abstract}

Keywords: heritage, memory, urban space.

\section{Resumo}

Neste artigo o autor focaliza os diferentes pontos de vista da população de um determinado subúrbio do Rio de Janeiro sobre os conceitos de patrimônio, memória e espaço. Diante de um processo de transformação urbana radical conduzido pela prefeitura da cidade sobre o espaço do seu bairro, eles discutem o destino de um velho cinema ameaçado de demolição. Alguns o entendem como um patrimônio a ser protegido e preservado porque supostamente expressa a memória do bairro. Outros defendem a tese de que o velho prédio deveria ser demolido e em seu lugar construída uma nova praça pública. Para o autor, estamos diante de dois modos distintos de entender o conceito de patrimônio: um deles baseado numa perspectiva abstrata e jurídica; um outro baseado na experiência de vida cotidiana dos moradores.

Palavras-chave: herança, memória, espaço urbano 


\section{The Dark Side of the Moon}

Heritage, memory and place in Rio de Janeiro, Brazil

José Reginaldo Santos Gonçalves

\section{Heritage as a native category}

Public and academic debates about "heritage" - generally understood as a form of "collective memory" - have increased in recent decades. The literature is quite extensive, and no comprehensive review will be undertaken.. ${ }^{1}$ Both categories have been submitted to investigations and inquiries in many disciplines, and have been distinctly present in the political agenda of social movements and government policies. It is difficult to ignore their presence in the social and political life of great cities, where dialogs and confrontations take place, expressing antagonistic concepts of space, time and identity. The current transformation processes of urban spaces - as well as efforts towards their legitimization and questioning - necessarily involve memory and heritage institutions and agents. They also involve the individual and collective responses of city residents to the projects conducted by those institutions and agents.

This process has evolved for decades in Brazil. The theme has been strongly present in the communication media and in the academic world, and is a legitimate field of studies in various disciplinary areas, mainly but not exclusively in Anthropology. ${ }^{2}$ In my work I have insisted on the need to qualify the category "heritage," exploring its native conceptions, and thus distance ourselves from its ideological and legal uses. ${ }^{3}$ Therefore, I've also been focusing on the idea that, from the native point of view, heritages always exist in specific, material forms and are built and noticed by means of sensitive codes

$1 \quad$ For some recent work see Nelson; Olin 2003; Assman 2011; Olick; Vinitzky;-Seroussi; Levy 2011.

2 See Arantes 1984; 2000; Gouveia; Miceli 1985; Gonçalves 2004; 2005; 2007; 2012; Chuva 2009; Abreu; Chagas 2010 [2003]; Rubino 1991; Santos 1992; Fonseca 1997; Lima Filho, M.F.; Eckert, C.; Beltrão, J. 2007; Santos 1992; Tamaso; Lima Filho 2012.

3 See Gonçalves 2008; 2008a; 2012. 
- sight, touch, smell, hearing, taste - and not only as abstract formulations that belong to programmatic discourses. Moreover, I insist that they exist as material objects situated in certain specific modalities of space, inseparable from the human experience and consequently from the "body techniques." In this sense, it is impossible to study "immaterial heritage" without focusing on its eminently material dimensions, its social and individual uses, as well as its production and effects. ${ }^{5}$

The importance of heritage consists in the fact that it performs a decisive role in the articulation of individual and collective narratives about memory and identity. It also offers a material and visible dimension to these narratives in the public space. Beyond that, when seen from the native point of view, heritage exists as part of its users' experience. It is in this context that it is perceived, used, transformed and destroyed. Heritage is significantly integrated into the everyday existence of individuals and social groups.

Once the categories of social memory and heritage began to circulate broadly in the social and political world, they inevitably took on a highly objectified form. That is, they came to be seen as objects to be identified, preserved or reconstructed by individuals or social groups. Heritage is understood to be a legal entity subjected to public or private property laws. It is the object of preservation policies: as are buildings that are officially classified as heritage sites ${ }^{6}$ by the National Historic and Artistic Heritage Institute (IPHAN) or as elements of "intangible heritage" like popular rituals, forms of popular cuisine and popular medicine, festivals like carnival, etc. A building to be officially recognized and protected by IPHAN is collectively perceived as a physical and symbolic unity (besides being a legal entity) that supposedly exists independently from the context of everyday social and cultural relations.

The social, political and legal uses of the categories "heritage" (and "collective memory") frequently tend to have anthropological and sociological studies understand heritage as an object in itself, and not as something that exists in a vast network of social and cultural relations. One of this article's objectives is to explore some native points of view on heritage and memory

4 Mauss 2003: 401-424.

5 See Gonçalves 2005; 2007; 2012.

6 In Portuguese: "bens tombados". 
and situate them as part of that web of social and cultural relations.

\section{A huge construction site}

Due to the projects designed for the events of the football World Cup in 2014 and the Olympics in 2016, the city of Rio de Janeiro has been described in the last few years as a large "construction site," especially by engineers, architects and urban planners. This metaphor is usually brought up in official discourses in a triumphant manner. In the specific case of the large network of roads that cut through various neighborhoods in the outer neighborhoods of Rio de Janeiro, a series of complicated consequences has reached the people who live in and drive through these areas. As we have extensively seen in the communication media, thousands of people have been displaced from their homes due to the need to demolish buildings and widen streets and avenues to create space for large roads. Besides demolitions and other changes that may be seen as positive or negative, these construction projects trigger a series of collective responses by the population. These responses tend to vary. Some people defend their housing against damage and seek financial compensation from the state; others defend the preservation of areas and buildings that are symbolically associated to the population's life and socially recognized as "heritage," a concept which, as we know, takes on varied semantic forms.

One of the construction projects undertaken by the Rio de Janeiro city government is the Transcarioca Corridor, a major expressway running from the Barra da Tijuca neighborhood to the Tom Jobim International Airport. The route cuts through a series of neighborhoods and has led to the demolition of many buildings. The purpose of the highway is to significantly reduce commuting time between Barra da Tijuca and the Tom Jobim International Airport. These demolitions are seen to be necessary by the city government because, along most of its route, the Transcarioca Corridor will be built at the level of the existing streets and avenues, will have to be widened in many places, which implies the demolition of buildings. The Transcarioca route crosses the neighborhoods of Barra da Tijuca, Jacarepaguá, Madureira, Bonsucesso, Ramos, Irajá, Vaz Lobo, Vicente de Carvalho and Brás de Pina up to Largo da Penha, where there will be a connection to the Ilha do Fundão and Tom Jobim International Airport. The estimated cost is more than a billion 
Reals (US\$500 million) and the construction, started in 2011, is expected to be partially finished in 2013. The prediction was that approximately 3,630 buildings would be demolished along the Transcarioca route. ${ }^{7}$ In addition to the Transcarioca, there are two other road projects: the Transoeste and the Transolímpica. ${ }^{8}$

The reflections developed in this article ${ }^{9}$ have been raised by the stories I have heard about the actual conditions and destiny of a movie theater in Vaz Lobo ("Cine Vaz Lobo"), a neighborhood situated along the Transcarioca route. As has happened to thousands of other structures along the routes of the recent road construction in the city of Rio de Janeiro, the Vaz Lobo movie theater was identified for demolition to widen an avenue. The Vaz Lobo movie theater is located at 4 Vicente de Carvalho Avenue, in front of the Vaz Lobo Square. The neighborhood of Vaz Lobo borders the neighborhoods of Irajá, Vicente de Carvalho, Rocha Miranda, Turiaçu, Cavalcante and Madureira. Vaz Lobo has 110 hectares and a population of approximately 14,041 inhabitants, ${ }^{10}$ with a total of 5,333 residences. Vaz Lobo is part of the XV Administrative Region of Rio de Janeiro, which includes the neighborhoods of Bento Ribeiro, Campinho, Cascadura, Cavalcante, Engenheiro Leal, Honório Gurgel, Madureira, Marechal Hermes, Osvaldo Cruz, Quintino Bocaiúva, Rocha Miranda and Turiaçu. Three important avenues in Rio de Janeiro's suburbs come to meet precisely at Vaz lobo Square, where the Vaz Lobo Theater is located: Avenida Ministro Edgar Romero., Avenida Monsenhor Felix, and Avenida Vicente de Carvalho.

\footnotetext{
7 See http://pt.wikipedia.org/wiki/TransCarioca Access 08/03/2012.

8 See http://www.youtube.com/watch?v=a/44BVhQAkY Access 08/03/2012.

9 The data presented here is the result of a research project I have been working on in the last two years with members of LAARES (The Laboratory for the Anthropology of Architecture and Places) in the Graduate Program in Sociology and Anthropology / IFCS / UFRJ (www.laares-ufrj.com), with the support of CNPq, CAPES and FAPERJ. Our studies have focused on the concepts of "place," "architecture" and "urbanism" in various social segments in the context of large cities, exploring these notions in the discourses of professionals of engineering, architecture, urbanism and historical preservation as well as in the discourses of residents and agents of local social movements. Currently, the empirical focus of our observation and analysis has been the effects of the big projects for urban intervention in the city of Rio de Janeiro given the 2014 World Cup and the 2016 Olympic Games. Fieldwork, participant observation and interviews have been concentrated in the neighborhoods of Vaz Lobo, Madureira and Irajá.

10 Information found on the website Bairros Cariocas of the Rio de Janeiro city government: http:/ portalgeo.rio.rj.gov.br/bairroscariocas/index_bairro.htm Accessed on March 8, 2012.
} 


\section{The Vaz Lobo movie theater as heritage}

According to stories told by the interviewees, ${ }^{113}$ the Vaz Lobo Theater was built in 1939 during the Estado Novo, as the dictatorial regime led by Getulio Vargas from 1937 through 1954 was known. It was inaugurated in 1941 and closed in $1982,{ }^{12}$ never to reopen again. Along these thirty years it was never used as an Evangelical church, a supermarket or a bank, as were many movie theaters in Rio de Janeiro in recent decades. This supposedly did not happen because the former owner, Manuel Mendes Monteiro, refused many proposals to sell the building. The theater has remained closed. In addition to the movie theater, the building had commercial stores on the ground floor, a few of which are still occupied, and a few apartments on the two upper floors. One of Manuel Mendes Monteiro's daughters lives there. She is the only resident of the building. According to some interviewees, she used to live with her mother in the building until a short while ago, but now lives alone. The other apartments are said to be empty. According to the stories I heard from my interviewees, she doesn't allow anyone into the theater. Many stories are said to be told about the current state of the auditorium. Although it is said that nobody has visited it in three decades, they describe it as sumptuous, supposedly having a sophisticated lighting system as well as what was considered at the time of its construction the largest architectural span ever built in the city. According to these testimonies, the room is equipped for up to 1,800 people. Some say all of the chairs have already been sold. But none of the people I interviewed were able to confirm this. They also could not say when, for how much or to whom they were sold. But they repeatedly assured me that there are no more chairs. They also say the lighting system still works. According to some interviewees, an electrician hired by the heiress was the one who passed on this information. They also say there is still projection equipment there, but they are unable to say what kind and its condition.

11 These narratives were put together on the basis of interviews conducted with members of the "Cine Vaz Lobo Movement" which is fighting for the preservation of the movie theater and its transformation into a cultural center. I would especially like to thank Mr. Ronaldo Luis Martins, a retired public employee and founder of the Historical and Geographical Institute of Irajá; Dr. Dr. Gusmão, a retired lawyer; Karen da Silva Barros, a historian; Maria Celeste, historian and elementary school teacher; and Fernanda Costa, an architect who was responsible for the route conversion project of Transcarioca in the portion where the road reaches the Vaz Lobo movie theater. I thank them all for their kind and generous reception of the research team.

12 For pictures of the Vaz Lobo movie theater see

https:/www.google.com/search?q=cine+vaz+lobo\&tbm=isch. Accessed on March14, 2013. 
Manuel Mendes Monteiro died in 2009. In that same year the Rio de Janeiro city government announced the Transcarioca Corridor project. But it was only initiated in 2011. Then, a local social movement for the preservation of the Vaz Lobo movie theater pushed the city government to officially announce a change in the highway route, assuring that the movie theater would remain where it was. There was also a project for rebuilding the Vaz Lobo Square. ${ }^{13}$ The original movement for the preservation of this movie theater became larger and turned into what today is known as "Movimento Cine Vaz Lobo: preservação, cultura e memória” (Cine Vaz Lobo Movement: preservation, culture and memory"). The movement has extended its efforts to the preservation and recognition of other buildings and historic places as "heritage sites" in Vaz Lobo, Irajá and surrounding areas. According to some of the people I interviewed, the Movement has also had repercussions on surrounding neighborhoods whose residents decided to gather in defense of the preservation of some of their public spaces and buildings, including old movie theaters.

One could surely say that this is a very common story: an old neighborhood movie theater threatened by probable demolition and the subsequent social mobilization of the local population regarding its preservation as "heritage." But what distinguishes the "Cine Vaz Lobo Movement" is precisely the way its members understand the notion of "heritage."

According to the engineers and urban planners of the city's department of public works, ${ }^{14}$ who are involved in the Transcarioca Corridor project, the Vaz Lobo movie theater building was considered an obstacle in the process of widening the pathway for the road construction and as such the project called for it to be demolished. However, according to people who worked at the time in the Secretariat of Cultural Heritage ${ }^{15}$ of Rio de Janeiro, the movie theater (according to a 2006 project) should be preserved as "heritage" because it was a "street movie theater" and was associated to an important moment in the history of the neighborhood, the city and the movie theaters of Rio de Janeiro. The members of the Cine Vaz Lobo Movement, perceive it in a

13 See http://vejario.abril.com.br/blog/as-ruas-do-rio/bairro-a-bairro/o-largo-de-vaz-lobo-estava-namira-da-transcarioca Access 08.03.2012.

14 In Portuguese: "Secretaria de Obras".

15 In Portuguese: “Secretaria de Patrimônio Cultural”. 
different way, but also claim the building should be considered "heritage,"

Why did a movie theater without great architectural value, classified by specialists as "late art deco", without any other attributes to distinguish it, and which has been closed for approximately 30 years, come to awaken the interest and memory of specific segments of the population of that neighborhood? It is important to point out that this is not an isolated event. In Rio de Janeiro and many other Brazilian cities in recent years there has been a broad movement for the preservation of the so called "street movie theaters," an expression that is used to distinguish them from movie theaters located in shopping centers. The Vaz Lobo movie theater is classified as one of these "street movie theaters." From the point of view of the agents of the pro "street movie theaters" movement, it is public space that is mainly appreciated as a source of social and individual life - not private space. In this way, the decline of the so called "street movie theaters" - because of the city's population growth, real estate speculation, the construction of shopping centers and the emergence of new media - is seen as one of the reasons for the decline of social life. From their point of view, this has dangerously led to what is called the "desertification of public space."16

The ideas of the members of the Cine Vaz Lobo Movement differ from those of the members of the movement for the "street movie theaters." Firstly, because the latter is situated in a generic plan and when they refer to the Vaz Lobo movie theater, it is presented as just an example of the general category "street movie theaters." In addition, in the case of the broader movements in defense of "street movie theaters" there is a clear and explicit project to reopen these theaters, and have them operate with financial support from the city government. In contrast, the members of the Cine Vaz Lobo Movement affirm that the Vaz Lobo movie theater has been unique since its inauguration until today. The Vaz Lobo movie theater became a powerful icon and the name of the Movement clearly isn't an accident. Unlike the movements in defense of "street movie theaters," the Cine Vaz Lobo Movement members do not present such a clearly defined project for the future uses of the building. They foresee a wide range of uses: it could become a cultural center, a performing arts center, the headquarters for the Historical and

16 See http://escrevendo1.blogspot.com.br/2012/03/movimento-pela-reativacao-dos-cinemas.html Access 08.03.2012. 
Geographical Institute of Irajá and so on.

The social nucleus of the Cine Vaz Lobo Movement is composed of local residents, some of them are people like Ronaldo Luis Martins, a 70-year old local historian who studies the region; Doctor Gusmão, a retired lawyer and childhood friend of Ronaldo, although the two only met again because of the Movement. Ronaldo now lives in the neighborhood of Freguesia. Doctor Gusmão still lives in Vaz Lobo. Other members are very young, such as Karen da Silva Barros who recently earned a bachelor's degree in history; Maria Celeste, who is also a historian as well as a local public school teacher; and Fernanda Costa, an architect and urban planner who was responsible for the project that led to the route change for the Transcarioca Corridor, rescuing the building of the Vaz Lobo movie theater from imminent demolition. They are the main social and cultural mediators of the Movement. They are the ones who take the initiative to contact city hall, and politicians from Rio de Janeiro State and in Brasilia. They publicize information about Vaz Lobo and especially about the Vaz Lobo movie theater. ${ }^{17}$

Apparently until the year of 2009, when the the Transcarioca Corridor was announced, and the Movement for the Vaz Lobo movie theater preservation began, very few people were aware of its existence. The building, in bad condition, did not arouse great attention or interest on the part of the local residents. According to some of the people I interviewed, the city government had a project for its recognition as "heritage" in 2006. Not for its architectural attributes, but for being recognized as one of the remaining "street movie theaters" of Rio de Janeiro. According to the members of the Movement, this project, for unclear reasons, was aborted. The resumption of the Vaz Lobo movie theater preservation project is due to circumstantial factors.

According to the interviewees, in 2009, a young architecture and urban planning student at the Federal Fluminense University (UFF), Fernanda Costa, had to choose a theme for her final course project. She decided to study the restoration of art deco movie theaters in the city of Rio de Janeiro. Although she lived in the neighborhood of Vaz Lobo since she was born, it was only then that she realized the existence of the old Vaz Lobo movie theater. It was a perfect fit for her paper. When I interviewed her, she said at first

17 See http://www.joaodorio.com/site/index.php?option=com_content\&task=view\&id=659\&Itemid=127. Access 08.03.2012. 
that she couldn't manage to gather much information about the movie theater from her relatives and neighbors. People said they knew of the existence of the movie theater, but they didn't remember going there to see a film. And even when talking to other residents, she couldn't get a positive answer when she asked about memories regarding the movie theater. According to Fernanda, given the difficulties, she had to look for other resources for her research on the Vaz Lobo movie theater. That's when they suggested she contact Ronaldo Luís Martins, who is acknowledged in the neighborhood as someone who knows a lot about Vaz Lobo and the neighboring region, and is the author of a book about the Madureira Market ("Mercadão de Madureira"). ${ }^{18}$ Since she couldn't have access to the inside of the theater, it was through Ronaldo's biographical memory that Fernanda managed to reconstruct what must have been the inside of the screening room. According to her, Ronaldo drew the room as he had kept it in his memory, since he went to the theater regularly when he was young.

In one of her meetings with Ronaldo to obtain information about the Vaz Lobo theater, Fernanda heard his commentary that "there was no way out," meaning that the route planned for the Transcarioca Corridor would definitely require demolishing the movie theater. Fernanda affirmed that "it wasn't really like that" and that there were possibilities to avoid the demolition. She had already been to the Pereira Passos Institute (an urban research institute in Rio de Janeiro), when she found an old project to officially recognize the building as a heritage site. Based on this project and archival research, she gained access to the Vaz Lobo movie theater's original architectural plans. Fernanda designed a new project that would be proposed to the Rio de Janeiro city government asking for the building's classification as heritage and the change of the Transcarioca Corridor route, thus preventing the Vaz Lobo movie theater from being demolished.. This initiative took place at the same time that the leaders of the Movement tried to gather the local population to sign a document to be submitted to the city mayor. They contacted a few politicians, including federal level politicians to obtain support for this initiative. After two years, the city government finally answered positively and the Transcarioca Corridor route near the Vaz Lobo Square stretch was altered, ensuring the building's permanence. As we will see below, this decision was

18 See http://www.mercadaodemadureira.com/e-book-mercadao-de-madureira.pdf. Access 04.13.2013. 
not consensually received by the neighborhood residents, although it was enthusiastically celebrated by the members of the Cine Vaz Lobo Movement.

We may say that through the narratives and images produced by the members of the Cine Vaz Lobo Movement, the building came to be perceived in a new light. It was no longer just an old abandoned and ignored building in Vaz Lobo Square, whose surrounding area was used by residents, those who frequented the local stores and bars, and people who attended a Pentecostal temple and a Catholic church in the area; it was no longer a building whose surrounding area was occupied by a marginal population, especially late at night. In a certain way, the Vaz Lobo movie theater came to be metaphorically "re-inaugurated," and seemed to gain new life.

The focus of these images and stories is the very origin of the movie theater in a historical time of population growth, and social and economic development of the outer neighborhoods of Rio de Janeiro, namely the 1930's and 1940's. ${ }^{19}$ The focus is also its inauguration as a luxurious movie theater with 1,800 seats, its use by residents during the 1940's, 50's and 6o's and after that, its decline through the 7o's with the drop in attendance, the declining local population, the real estate depreciation and the closing of the movie theater in the eighties, as occurred with so many other movie theaters in Rio de Janeiro and other Brazilian cities.

The interviewees emphasize that, in contrast to many others in the city, the Vaz Lobo movie theater was not turned into a Pentecostal church or a supermarket, although, according to them, Mr. Monteiro received many valuable offers. According to some people, he wanted to turn the movie theater into a "cultural center" and for that reason he rejected all the offers he had received to sell or rent it. The building has remained closed since 1982. In the narratives I had access to, nobody explained why one of the owner's daughters, who lives in the building, prohibits anyone from entering. ${ }^{204}$ They insist

19 See Oliveira, Marcio Piñon de; Fernandes, Nelson da Nóbrega (2010).

20 If more carefully investigated, these narratives of the Cine Vaz Lobo Movement provide evidence of a curious point: they insistently emphasize that the movie theater was never reopened and that it remains closed. Apparently, in this narrative context the theater represents something more than a simple register of a historical fact. The building is part of a set of elements among which it seems to have an important role, suggesting that the narrative provides evidence of a mythical dimension, in which the movie theater operates transitions in the space and time of the neighborhood universe. In the interviews, the leaders of the movement obsessively repeat this information, implying that this magically singularizes the Vaz Lobo movie theater. It is possible to investigate here the relations between myth and heritage narratives. I have explored this possibility in an article not yet published. (Gonçalves 2013). 
on the fact that the movie theater has "resisted" all these years and in a joking manner suggest that the theater has a "corpo fechado." 215

As a spatial and architectural structure situated at one of the neighborhood's reference points, the intersection of three important avenues in the Rio de Janeiro suburbs, it was a catalyst for the members of the Movement as for a series of biographical and historical narratives. One of the people I interviewed reports that in one of the demonstrations promoted by the Cine Vaz Lobo Movement in front of the building, a large number of people signed the petition to be sent to the mayor, and some were looking for the leaders of the Movement to give them family photographs and old newspaper articles about the Vaz Lobo movie theater. According to these interviewees, there was a very positive repercussion among the local population. But they also said there were those who simply argued for the demolition of the building and the construction of a new square in that space. For these people, the building and its surrounding area were considered dangerous, since at times it is used by drug dealers and drug users. Some said the best solution would be to demolish the building. Obviously there was no consensus. However, the interviewees who are members of the Movement affirmed unanimously that the neighborhood residents were very supportive.

\section{From some residents' point of view}

We have presented the point of view of the leaders of the Cine Vaz Lobo Movement. The stories they tell about the origin and current situation of the Vaz Lobo movie theater may be understood as a result of an effort to frame a "collective memory." ${ }^{22}$ The preservation project for the Vaz Lobo movie theater, its reconstruction through narratives, photographs, old newspaper articles, plans, drawings that imaginarily reproduce the auditorium can be interpreted as an expression of such an effort.

However, although the members of the Movement point out the positive reception they have had from many neighborhood residents, they also indicate that there have been difficulties in relations with the population.

\footnotetext{
21 "Corpo fechado" (protected body) is a concept used by Afro-Brazilian religions to designate a magical condition of absolute protection from any harm, which may be directed against a person.

22 See Pollak 1993.
} 
Fernanda Costa tells about her difficulties in obtaining precise memories about the movie theater from her relatives and other old residents of the neighborhood. She even says that she used to walk in front of the Vaz Lobo movie theater everyday and it didn't call her attention at all. She simply didn't notice its existence in the neighborhood's everyday life. It was a kind of non-existent space. It was only when she faced the academic task of writing a paper on an old art nouveau movie theater that she came to notice that there was one very close to her house, although not among the most significant ones. She then decided to write her final paper about this movie theater. After that, she contacted the Pereira Passos Institute and Ronaldo Luís Martins to obtain more information about the movie theater. Michael Pollak's ${ }^{23}$ concept of "memory entrepreneurs" is useful in describing her action.

But considering that any effort to frame memory is limited, however intense and rigorous it may be, and since there is no memory narrative that is total, homogeneous and without fissures and contradictions, we may ask: to what degree do these narratives express the life of the movie theater? Would it be possible to find some kind of "resonance" ${ }^{24}$ of the Movement leaders' point of view among the residents of that neighborhood?

In a certain way, if we accept what the Movement's leaders say, we could answer the question positively. But, as we have seen, they are the ones who recognize that some local residents call for the demolition of the movie theater and a radical transformation of its surroundings. When asked, many residents said they were unaware of plans to preserve the movie theater, that they didn't see such an initiative positively and preferred that the whole area be turned into a square. ${ }^{256}$ Others said that the area has been occupied by drug dealers and drug addicts. One of the interviewees said that those who defend the preservation of the building don't have wide support from the local population of Vaz Lobo and in order to get the signatures for the project support they had to go to a place outside the neighborhood, the Madureira Market ("Mercadão de Madureira"), which is known as a central social and

\footnotetext{
23 See Pollak 1993:30.

24 See Gonçalves 2005.

25 The researcher Luzimar Paes Barros has collected this information. She did informal interviews in Vaz Lobo Square in December 2012 and January 2013, by talking to people in bars, shops, coconut vendors and people who attend the Catholic Church as well as a Pentecostal temple in the area near the Vaz Lobo movie theater (Barros 2013).
} 
commercial point in the on the outskirts of Rio de Janeiro. They say that the building is very old and decadent, in very bad condition, and infested by rats and insects. When interviewed, the Catholic priest said many people who attend the church asked him to use his social prestige to intervene and help block the preservation of the movie theater. Apparently, at no time did the residents interviewed see the construction of the Transcarioca and the possible demolition of the Vaz Lobo movie theater building as a real threat. One of them said that after the change in the project, the road would become wider and even more dangerous for the pedestrians who have to cross it, and predicts a rise in the number of fatal accidents on the road. For them, the original project should have been used, and the movie theater demolished.

\section{Heritage, space and experience}

There is a common aspect between the point of view of the members of the Movement for the preservation of "street movie theaters" at the national level ${ }^{26}$ and the point of view of the leaders of the Cine Vaz Lobo Movement. They both emphasize unity in framing the memory of the local movie theater and the neighborhood; they both share a concept of heritage that emerges in the abstract world of laws and cultural ideologies; they both share a homogeneous and continuous concept of time when telling the history of the Vaz Lobo movie theater from its origin to present days. To the extent that this is a history of decline, their intention is to interrupt this process and rescue the building from destruction, thus enacting a narrative that I call the " rhetoric of loss." 27

On the other hand, those who simply ignore or are in fact in explicit opposition to the project to preserve the Vaz Lobo movie theater share a concept of heritage that emerges from their everyday life experience as well as from their biographical memory as neighborhood residents. This is to say that considering this point of view we may primarily talk of multiple heritages as well as multiple memories. We should ask ourselves if we still recognize "heritage" as a legal, social and symbolic element in their discourse.

26 A point of view that is expressed by Rio de Janeiro government employees who conducted an aborted project of classifying the Vaz Lobo movie theater as heritage in 2006.

27 See Gonçalves 2004. 
In the process of being classified as heritage, the movie theater is no longer the center, but part of a wider spatial and social world. It should be stressed that from the residents' point of view heritage emerges from their existential perception of the space, from their daily passage through the neighborhood streets and from what the latter may offer them in terms of familiarity or strangeness, safety or danger. Their interest is not exactly the Vaz Lobo movie theater as a cultural or legal unit to be preserved, but the neighborhood as a whole, the streets, the house where they live, the streets they roam, the avenues and the traffic, and also the Vaz Lobo Square, where close to so many other buildings the Vaz Lobo movie theater once - but no longer - operated. For them, it is not therefore an abstract and homogenous concept of space, but a qualitative one composed of heterogeneous places, which are first and foremost inhabited, more than perceived and classified as preservation sites. Moreover, they are not telling the neighborhood history from the perspective of a possible "loss," as do those who defend the preservation of the Vaz Lobo movie theater. They don't see the neighborhood and its streets being threatened by a loss. Many see the Transcarioca construction as positive because, according to them, it will bring improvements to the neighborhood. On the other hand, the threat that haunts many throughout the whole length of these great road constructions is the possibility that the construction may require the expropriation and demolition of their homes. In this case, it's a matter of a material loss, which is not usually mentioned by those who focus on the preservation of the Vaz Lobo movie theater.

If we were to graphically represent the concepts of space expressed by one or the other group, we'd have on one hand a homogenous surface with the Vaz Lobo movie theater in the center and identified as heritage, as a unit valued in itself, associated to immaterial values and, in this sense, separated from the everyday life around it. From the other point of view, we'd have a heterogeneous space, a meshwork of streets, avenues, houses, squares, buildings, with reference points, boundaries and frontiers used by the residents in their everyday life. So, if there is a central point, it is not occupied by the Vaz Lobo movie theater but perhaps by a certain square, a church, a commercial establishment, in relation to which the proposal to preserve or to classify the theater as "heritage" is not necessarily in their horizons. Not the concept of heritage as a legally and culturally delimited unit to be preserved. This grid of perception is a lot more complex than that of the people who defend 
the Vaz Lobo movie theater preservation as an expressive heritage of the neighborhood. This is the difference between those who actually live in the neighborhood and those who, although they may live there, perceive it from a distanced perspective as a target of cultural preservation, identifying themselves with the Cine Vaz Lobo Movement. For the latter, the Vaz Lobo movie theater is more than part of their everyday life, it is the place that symbolically synthetizes a certain way of telling the history of the movie theater and the neighborhood.

If we explore the suggestion to think of heritage as a "native category," that social situation can be understood in different ways. Moreover, the understanding presupposes distinct modalities of perceiving the local sociocultural world. From the point of view of many inhabitants, the Vaz Lobo movie theater is not an independent material and cultural element. It is perceived as part of a problematic and differently occupied physical and social environment. In this context, the very idea of "heritage" loses its abstract and unified character and becomes part of the inhabitants' complex and diverse everyday life experience. All things considered, heritage is not necessarily for them a set of material objects and architectural structures to be preserved, but strategies for living within the spatial limits of their neighborhood. Less than a heritage to be preserved, it is a heritage to be lived as part of their everyday life. Paraphrasing Walter Benjamin, these people could well say: "Why preserve the Vaz Lobo movie theater, if it is divorced from our experience?" ${ }^{28}$

Translaed by Isadora Contins

Accepted for publication on February 22, 2013.

\section{Bibliography}

ABREU, Regina; CHAGAS, Mário (orgs.). 2010 [2003]. Patrimônio e memória: ensaios contemporâneos. Rio de Janeiro: Ed. Lamparina.

ABREU, Regina; SANTOS, Myrian Sepulveda (orgs.). 2007. Museus, coleções e patrimônios: narrativas polifônicas. Rio de Janeiro: Iphan/ Garamond. Col. Museu, Memória e Cidadania.

ARANTES, Antonio Augusto. 1984. Produzindo o passado: estratégias de

28 "For what is the value of all our culture if it is divorced from experience" (Benjamin, 1996 [1933]: 732). 
construção do patrimônio cultural. São Paulo: Brasiliense.

ARANTES, Antonio Augusto. 2000. Paisagens paulistanas: transformações do espaço público. 1a. ed. Campinas: Unicamp.

ASSMANN, Aleida. 2011. Cultural memory and western civilization. Functions, media, archives. Cambridge: Cambridge University Press.

BARROS, Luzimar Paes. 2013. "O cine Vaz Lobo". Final Paper. Departamento de Antropologia Cultural. IFCS / UFRJ.

BENJAMIN, Walter. 1996. "Experience and poverty". In: Michael W. Jennings; Howard Eiland; Gary Smith (eds.), Walter Benjamin: selected writings. vol. 2, part 2, 1931-1934. Cambridge, MA: Harvard University Press. pp. 731-736

CHUVA, Marcia. 2009. Os arquitetos da memória: sociogênese das práticas de preservação do patrimônio cultural no Brasil. 1a. ed. Rio de Janeiro: Editora UFRJ.

FONSECA, Maria Cecília Londres. 1997. O patrimônio em processo: trajetória da política federal de preservação no Brasil. Rio de Janeiro: Ed. UFRJ/ MINCIPHAN.

GOUVEIA, Maria Alice; MICELI, Sergio. 1985. Política cultural comparada. Rio de Janeiro: FUNARTE/FINEP/IDESP.

GONÇALVES, José Reginaldo Santos. 2004 [1996]. A retórica da perda: discurso nacionalista e patrimônio cultural no Brasil. Rio de Janeiro: Editora da UFRJ.

GONÇALVES, José Reginaldo Santos. 2005. "Ressonância, materialidade e subjetividade: as culturas como patrimônios". In: Horizontes Antropológicos, 11(23): pp. 15-36..

GONÇALVES, José Reginaldo Santos. 2007. “Os limites do patrimônio”. In: Manuel Ferreira Lima Filho; Cornelia Eckert; Jane Beltrão (orgs.), Antropologia e patrimônio cultural: diálogos e desafios contemporâneos. Blumenau: ABA, Nova Letra. pp. 239-248.

GONÇALVES, José Reginaldo Santos. 2012. "As transformações do patrimônio: da retórica da perda à reconstrução permanente”. In: Izabela Tamaso; Manuel Ferreira Lima Filho (orgs.), Antropologia e patrimônio cultural: trajetórias e conceitos. Brasília: ABA Publicações. pp. 59-74.

GONÇALVES, José Reginaldo Santos. 2013. "Mito e patrimônio num subúrbio do Rio de Janeiro". Unpublished paper.

LIMA FILHO, Manuel Ferreira; ECKERT, Cornelia; BELTRÃO, Jane (orgs.). 2007. Antropologia e patrimônio cultural: diálogos e desafios contemporâneos. Blumenau: ABA, Nova Letra. 
MAUSS, Marcel. 2003. Sociologia e antropologia. São Paulo: Cosac \& Naif.

NELSON, Robert S.; OLIN, Margaret. 2003. Monuments and memory, made and unmade. Chicago: Chicago University Press.

OLICK, Jeffrey K.; VINITZKY-SEROUSSI; LEVY, Daniel. 2011. The collective memory reader. Oxford: Oxford University Press.

OLIVEIRA, Marcio Piñon de; FERNANDES, Nelson da Nóbrega (orgs.). 2010. 150 anos de subúrbio carioca. Niterói/ Rio de Janeiro: FAPERJ/Editora da UFF/ Lamparina.

POLLAK, Michael. 1993. Une identité blessée: études de sociologie et d'histoire. Paris: Éditions Métailié.

RUBINO, Silvana. 1991. As fachadas da história: os antecedentes, a criação e os trabalhos do Serviço do Patrimônio Histórico e Artístico Nacional, 1937-1968. Dissertação de Mestrado, Campinas, Universidade de Campinas.

SANTOS, Marisa Veloso Motta. 1992. O tecido do tempo: a ideia de patrimônio cultural no Brasil. Tese de Doutorado, Brasília, Departamento de Antropologia, Universidade de Brasília.

TAMASO, Izabela; LIMA FILHO, Manuel Ferreira. 2012. Antropologia e patrimônio cultural: trajetórias e conceitos. Brasília: ABA Publicações. 